J. Clin. Chem. Clin. Biochem.

Vol. 15, 1977, pp. 275-283

\title{
Drug Screening by Enzyme Immunoassay (EMIT) and Thin-Layer Chromatography (Drug Skreen) ${ }^{1}$ )
}

\author{
By M. Oellerich, W. R. Külpmann and R. Haeckel
}

Technical Assistence: F. Behrends, I. Isberner and K. Petry

Institut für Klinische Chemie (Geschäftsführcnder Direktor: Prof. Dr. Dr. J. Büttner) Medizinische Hochschule Hannover

(Received June 12/December 16, 1976)

\section{Herrn Prof. Dr. Dr. h. c. G. Schettler zum 60. Geburtstag gewidmet}

Summary: Urine samples $(n=300)$ were examined for drugs by thin-layer chromatography ("Drug Skreen", Brinkmann Corp.) and by the "Enzyme Multiplied Immunoassay Technique" ("Emit", Syva Corp.). The results of both methods were compared for the detection of opiates, barbiturates and amphetamines. In more than $90 \%$ of the determinations identical results were obtained with both methods. About $10 \%$ of the results of the Emit barbiturate assay differed from those of thin-layer chromatography and therefore had to be further investigated by gas liquid chromatography. It could be demonstrated that the barbiturate determination by the Emit system correlated better with the results of gas liquid chromatography. From the results of this study it is suggested that thin-layer chromatography is used as a screening test, and to confirm positive results with other methods such as Emit. If the abuse of barbiturates or opiates is suspected the corresponding Emit test should also be performed, even in cases of a negative thin-layer chromatograph; screening. Confirmation with a third method such as gas liquid chromatography is necessary, if thin-layer chromatography and Emit lead to divergent results.

\section{Drogenscreening mit Enzymimmuntests (EMIT) und Dünnschichtchromatographie (Drug Skreen)}

Zusammenfassung: Urinproben $(n=300)$ wurden dünnschichtchromatographisch („Drug Skreen“, Brinkmann Corp.) und mit Enzymimmuntests („Emit“, Syva Corp.) auf Drogen untersucht. Die Ergebnisse beider Methoden wurden für den Nachweis von Opiaten, Barbituraten und Amphetaminen miteinander verglichen. In über $90 \%$ der Bestimmungen fanden sich identische Resultate mit beiden Methoden. Etwa 10\% der Ergebnisse des Emit Barbiturattests divergierten mit denen der Dünnschichtchromatographie und mußten daher zusätzlich gaschromatographisch untersucht werden. Es konnte gezeigt werden, daß die Barbituratbestimmung mit dem Emit System besser mit den Resultaten der Gaschromatographie korrelierte. Auf Grund der Ergebnisse dieser Studie wird vorgeschlagen, die Dünnschichtchromatographie als Screening-Test zu verwenden und positive Resultate mit anderen Methoden wie z. B. Emit zu bestätigen. Bei Verdacht auf Barbiturat- und Opiatmißbrauch ist die zusätzliche Durchführung des entsprechenden Emit-Testes auch in Fällen eines negativen Dünnschichtchromatographie-Screenings empfehlenswert. Die Bestätigung mit einem dritten Verfahren wie z. B. Gaschromatographie ist erforderlich, wenn Dünnschichtchromatographie und Emit zu divergenten Resultaten führen.

The treatment of drug overdosage and the detection of drug abuse require rapid analytical methods for the identification of drugs in biological material.

In the past few years many thin:layer chromatographic techniques for the detection of drugs have been described (1-7). Instead of the time-consuming extraction of drugs from urine with organic solvents, Amberlite XAD-2 columns were proposed (8-12). Combinations of drug extraction by XAD-2 resin with a thin-layer chromatographic screening technique (3) are commercially available.
The identification of drugs with thin-layer chromatographic techniques alone is difficult. Therefore drugs have been eluted from the thin-layer plate and subsequently examined by various methods such as color, microcrystal and UV spectrophotometric tests (13). However more specific, rapid and sensitive method's for the verification of thin-layer chromatographic results appear to be necessary. Several immunological

1) Parts of this study have been reported at Analytica 76 in Munich 1976 (abstract: Z. Anal. Chem. 279, 132 (1976)). 
methods such as radioimmunoassay, spin immunoassay, hemaglutination inhibition and enzyme immunoassay have also been applied for the detection of drugs (14-23).

In the present study an enzyme immunoassay system (Emit, Syva Corp.) was evaluated for its use in the confirmation of opiates, barbiturates and amphetamines detected by thin layer chromatography.

\section{Materials and Methods}

\section{Origin of specimens}

Urine samples $(n=300)$ were received from a drug abuse rehabilitation center, from the State Health Department Hannover, and from our hospital. Drug free control urine was obtained from laboratory personel. Lyophilized human urine spiked with various drugs (urine toxicology control proficiency and urine drug check kit) was purchased from Cyanamide GmbH (D-8000 Munich).

\section{Materials}

The reagents for the enzyme immunoassay (Emit) were purchased from Syva Corp., Palo Alto, Calif. and materials for thin-layer chromatography (Drug Skreen) from Macherey \& Nagel (D-5160 Düren). Materials for gas liquid chromatography were obtained from Supelco (Bellfonte, $\mathrm{Pa}, \mathrm{USA}$ ) and all other . chemicals from Merck AG (D-6100 Darmstadt).

Thin-layer chromatography (Drug Skreen)

Thin-layer chromatographic determinations were performed according to the manufacturer's instructions. The drugs were extracted by disposable Amberlite XAD-2 columns and separated by thin-layer chromatography on silica gel $\infty$ ated glass plates (solvent system: ethyl acetate/methanol $/ 330 \mathrm{~g} / 1$ ammonium hydroxide, $17 \mathrm{ml}+2 \mathrm{ml}+1 \mathrm{ml}$ ). For visualization of the drugs UV radiation, heat and group specific reagents were applied to the plates. With each plate a control urine was processed containing morphine, codeine, meperidine, methadone, amphetamine, pheno-, seco- and amorbarbital at levels of $1-3 \mathrm{mg} / \mathrm{l}$. The $\mathrm{Rf}$-values of drugs were calculated relative to amobarbital (1). Drugs were identified by their relative $R f$-value, color reaction and the comparison with the reference substances on the same plate. Detection criteria of various drugs are given in table 1 and 2. Blind controls were performed with toxicological control urine (urine drug check kit, Lederle Diagnostics).

\section{Enzyme immunoassay (Emit)}

The original procedure of the enzyme immunoassay for the detection of drugs in urine (18) was slightly modified to incorporate the Eppendorf system 5085 (tab. 3). The further evaluation of the results was performed according to the manufacturer's instructions. At the beginning and end of each series a urine sample spiked with the drug tested was analyzed as precision control. The quantitative determination of phenobarbital in serum by Emit was performed with an Eppendorf analyzer 5010 (tab. 4).

\section{Gas-liquid chromatography}

After the addition of $5 \mu \mathrm{g}$ hexobarbital as internal standard the urinary samples were purified by chromatography on Amberlite XAD-2. The eluates were evaporated under vacuum. The residues were dissolved in a small volume of ethyl acetate/acetic acid $(100 \mathrm{ml}+1 \mathrm{ml})$ and applied to an aluminium sheet coated with silica gel $\mathrm{F}_{254}$ (thickness of the layer $0.25 \mathrm{~mm}$ ). The chromatogram was developed with ethyl acetate/methanol $/ 330 \mathrm{~g} / \mathrm{l}$ ammonium hydroxide $(17 \mathrm{ml}+2 \mathrm{ml}+1 \mathrm{ml})$ and chloroform/ acetone $(8 \mathrm{ml}+2 \mathrm{ml})$ at right angles to the first direction. The zone containing the barbiturates was cut off and put into a glass tube with a sealed-in sintered glass support $(G 4)$ at the bottom.
Tab. 1. Detection criteria for hypnotics and sedatives.

\begin{tabular}{|c|c|c|}
\hline Compounds (trade name) & $R_{f}$ value $^{a}$ & $\begin{array}{l}\text { Color reaction } \\
\text { with diphenyl- } \\
\text { carbazone/mer- } \\
\text { curic sulfate }\end{array}$ \\
\hline Phenobarbital (Luminal) & 0.54 & violet \\
\hline Brallobarbital & 0.70 & violet \\
\hline Barbital (Veronal) & 0.70 & violet \\
\hline Cyclobạrbital (Phanodorm) & 0.72 & violet \\
\hline Allobarbital (Dial) & 0.76 & white \\
\hline Propylallylónạl & 0.79 & violet \\
\hline Heptabarbital (Medomin) & 0.80 & violet \\
\hline Aprobarbital (Numal) & 0.89 & white \\
\hline Vinylbital & 0.89 & violet \\
\hline Methylphenobarbital (Prominal) & 0.91 & violet \\
\hline Crotylbarbital & 0.92 & violet \\
\hline Butalbital (Sandoptal) & 0.93 & white \\
\hline Cyclopal & 0.94 & white \\
\hline Amobarbital (Amytal) & 1.00 & violet \\
\hline Butabarbital & 1.03 & violet \\
\hline Pentobarbital (Neodorm) & 1.06 & violet \\
\hline Amylallylbarbital & $1: 06$ & violet \\
\hline Secobarbital (Seconal) & 1.09 & white \\
\hline Thiogenal & 1.16 & white \\
\hline Hexobarbital (Evipan) & 1.21 & violet \\
\hline Enibomal (Eunarcon) & 1.28 & violet \\
\hline Glutethimide (Doriden) & 1.64 & violet \\
\hline Methaqualone (Mandrax) ${ }^{b}$ & 1.77 & $N^{c}$ \\
\hline Carbromal (Adalin) & - & NR \\
\hline
\end{tabular}

a) Relative to amobarbital. Solvent system: ethyl acetate/ methanol $/ 330 \mathrm{~g} / \mathrm{l}$ ammonium hydroxide, $17 \mathrm{ml}+2 \mathrm{ml}+1 \mathrm{ml}$.

b) Positive reaction with iodoplatinate and Dragendorffs reagent.

9 No reaction.

Tab. 2. Detection criteria for various drugs.

\begin{tabular}{|c|c|c|c|}
\hline Compound (trade name) & $\begin{array}{l}R_{\mathbf{f}} \\
\text { value }^{a}\end{array}$ & $\begin{array}{l}\text { Nin- } \\
\text { hydrin }\end{array}$ & $\begin{array}{l}\text { Iodo- } \\
\text { platinate }\end{array}$ \\
\hline \multicolumn{4}{|l|}{ Narcotics } \\
\hline $\begin{array}{l}\text { Morphine } \\
\text { Codeine } \\
\text { Ketobemidone (Cliradon) } \\
\text { Levorphanol (Dromoran) } \\
\text { Pethidine (Dolantin) } \\
\text { Normethadone (Ticarda) } \\
\text { Levallorphan (Lorfan) } \\
\text { Methadone (L-Polamidon) } \\
\text { Methadone Metabolite }\end{array}$ & $\begin{array}{l}0.41 \\
0.72 \\
1.09 \\
1.19 \\
1.28 \\
1.28 \\
1.59 \\
1.64 \\
1.70\end{array}$ & $\begin{array}{l}\text { (pink) } \\
\text { (pink) }\end{array}$ & $\begin{array}{l}\text { dark blue } \\
\text { brown } \\
\text { brown } \\
\text { brown-violet } \\
\text { violet } \\
\text { brown } \\
\text { brown-violet } \\
\text { brown } \\
\text { brown }\end{array}$ \\
\hline Stimulants & & & \\
\hline $\begin{array}{l}\text { Methamphetamine (Pervitin) } \\
\text { Amphetamine (Benzedrin) } \\
\text { Strychnine } \\
\text { Fene thylline (Captagon) } \\
\text { Methylphenidate (Ritalin) } \\
\text { Bemegride (Eukraton) }\end{array}$ & $\begin{array}{l}0.68 \\
0.96 \\
0.68 \\
1.32 \\
1.43 \\
.=\end{array}$ & pink & $\begin{array}{l}\text { brown } \\
\text { brown-violet } \\
\text { brown-violet } \\
\text { brown-violet } \\
\text { NR }^{\text {b }}\end{array}$ \\
\hline \multicolumn{4}{|l|}{ Miscellaneous } \\
\hline $\begin{array}{l}\text { Quinine }^{c} \\
\text { 4-Aminophenazone } \\
\text { Propylhexedrine (Eventin) } \\
\text { Nicotine } \\
\text { Fenfluramine } \\
\text { Thioridazine (Melleril) } \\
\text { Diphenhydramine } \\
\text { Chlorpromazine (Megaphen) } \\
\text { Trifluopromazine (Psyquil) } \\
\text { Amitryptiline (Laroxyl) }\end{array}$ & $\begin{array}{l}0.72 \\
1.04 \\
1.05 \\
1.34 \\
1.43 \\
1.58 \\
1.58 \\
1.59 \\
1.61 \\
1.65\end{array}$ & pink & $\begin{array}{l}\text { brown } \\
\text { (pink) } \\
\text { brown } \\
\text { green } \\
\text { brown } \\
\text { brown-yellow } \\
\text { brown } \\
\text { blue-violet } \\
\text { brown-violet } \\
\text { brown }\end{array}$ \\
\hline
\end{tabular}

a) Relative to amobarbital. Solvent system: ethyl acetate/ methanol $/ 330 \mathrm{~g} / \mathrm{l}$ ammonium hydroxide, $17 \mathrm{ml}+2 \mathrm{ml}+1 \mathrm{ml}$.

b) No reaction.

9 fluorescence under uv-light. 
Tab. 3. Test procedure for the Emit drugs abuse urine assays with the Eppendorf system 5085.

Tris-maleate buffer $0.025 \mathrm{mmol} / 1 \mathrm{pH} 6.0$

Bacterial suspension

Urine sample

$750 \mu 1$

$200 \mu 1$

$50 \mu 1$

Preincubation: $10 \mathrm{~min}$ at $37^{\circ} \mathrm{C}$ in polystyrene cuvettes $(\mathrm{d}=1 \mathrm{~cm})$

Reagent A (antibody solution)

Reagent B (drug-enzyme conjugate)

$50 \mu 1$

$50 \mu 1$

Wavelength: $436 \mathrm{~nm}$. First reading of absorbance $10 \mathrm{~s}$ and second reading $34 s$ after addition of reagent $B$.

Tab. 4. Test procedure for the Emit phenobarbital assay with Eppendorf analyzer 5010 .

Serum $10 \mu l$

Reagent A (antibody/substrate/NAD) ${ }^{\mathrm{a}} \quad 500 \mu$ l

Preincubation: $15 \mathrm{~min}$ at $25^{\circ} \mathrm{C}$

Reagent B (drug-enzyme conjugate) ${ }^{a}$

$100 \mu 1$

Wavelength: $334 \mathrm{~nm}$, program GOT, temperature $25^{\circ} \mathrm{C}$. First reading of absorbance $30 \mathrm{~s}$ and last reading $180 \mathrm{~s}$ after addition of reagent $B$

a) Reagent $A$ is diluted $1: 13.5$ and reagent $B$ 1:2.5 with 55 $\mathrm{mmol} / \mathrm{l}$ Tris-HCl buffer ( $\mathrm{pH}$ 7.9).

Elution was carried out with $5 \mathrm{ml}$ chloroform/acetone $(8 \mathrm{ml}$ $+2 \mathrm{ml}$ ) and repeated once. The eluates were evaporated under vacuum and after dissolution in ethyl acetate/acetic acid $(100 \mathrm{ml}+1 \mathrm{ml})$ analyzed by gas-liquid chromatography on the following column packings: $3 \%$ SP-2250 DA Chromosorb WHP 100-200 mesh, 3\% Ov-101 on Chromosorb WHP 100-120 mesh, 3\% CDMC on Chromosorb WHP 100-120 mesh. A Varian gas chromatograph series 2800 equipped with a double flame ionisation detector and siliconized glass columns was used. The barbiturates were identified by comparison of their relative retention time (relative to hexobarbital) on various columns and as control by the simultaneous injection of the extract and the barbiturate supposed. The detection limit dependends on the individual barbiturate and was at least $0.2 \mathrm{mg} / \mathrm{l}$, if $20 \mathrm{ml}$ urine were processed (Külpmann, W. R. unpublished).

\section{Determination of detection limits}

Commercially available control urine (urine toxicology control drugs $I$, Lederle diagnostics) containing morphine ( $3 \mathrm{mg} / \mathrm{l})$, methadone $(3 \mathrm{mg} / \mathrm{l})$, amphetamine $(5 \mathrm{mg} / \mathrm{l})$ and secobarbital $(5 \mathrm{mg} / \mathrm{l})$ was diluted with drug free urine $1: 3,1: 5$ and $1: 10$. Then $20 \mathrm{ml}$ of each dilution were extracted and processed by thin layer chromatography. Concentrations at which spots just could be detected visually on the thin-layer chromatographic plate are given as the detection limits of the various compounds. With the various Emit assays the detection limits were determined according to Kaiser $(24)$ as the mean value plus the 3 fold standard deviation of a series $(n=20)$ from drug free, pooled urine.

\section{Results and Discussion}

\section{Precision of the Emit system}

The precision of the Emit assays for the detection of drugs in urine was low (tab. 5). Therefore only a semiquantitative evaluation of the results appears suitable. One reason for the low precision may be the turbidi- metric technique. Typical Emit standard curves are shown in figure 1. A better precision was found with the Emit assays for methadone and opiate than with those for amphetamine and barbiturate.

A considerable improvement of the precision and accuracy was achieved with the recently developed Emit assay for the quantitative determination of phenobarbital in serum (25-29). In this assay a NAD coupled reaction was applied. Moreover this assay could be mechanized with an Eppendorf analyzer 5010. The coefficient of variation of the Emit phenobarbital assay was $6.0 \%$ within series and $7.8 \%$ from day to day (mean value with standard deviation: $29.7 \pm 2.3 \mathrm{mg} / \mathrm{l}$; $n=40$ ). Similar results have been observed, when this Emit assay was performed on a Gilford spectrophotometer $(26,28)$.

Tab. 5. The precision of the Emit system for the detection of morphine $(2.3 \mathrm{mg} / \mathrm{l})$, methadone $(2.7 \mathrm{mg} / \mathrm{l})$, amphetamine $(2.2 \mathrm{mg} / \mathrm{l})$ and secobarbital $(2.8 \mathrm{mg} / \mathrm{l})$ in spiked human urine samples. Assays were performed in duplicate on 20 days $(n=40)$.

\begin{tabular}{|c|c|c|c|c|}
\hline Precision & $\begin{array}{l}\text { morphine } \\
\overline{\mathbf{x}}(\mathrm{CV})^{*}\end{array}$ & $\begin{array}{l}\text { methadone } \\
\overline{\mathbf{x}}(\mathrm{CV})\end{array}$ & $\begin{array}{l}\text { ampheta- } \\
\text { mine } \\
\bar{x}(C V)\end{array}$ & $\begin{array}{l}\text { secobarbital } \\
\bar{x}(\mathrm{CV})\end{array}$ \\
\hline $\begin{array}{l}\text { From } \\
\text { day- } \\
\text { to-day }\end{array}$ & $2.98(23.8)$ & $1.95(34.4)$ & $2.94(44.7)$ & $1.67(39.1)$ \\
\hline $\begin{array}{l}\text { Within } \\
\text { series }\end{array}$ & $2.98(13.7)$ & $1.95(13.3)$ & $2.94(32.9)$ & $1.67(31.4)$ \\
\hline
\end{tabular}

* mean value $(\overline{\mathbf{x}}, \mathrm{mg} / \mathrm{l})$ with coefficient of variation $(\mathrm{CV}, \%)$.

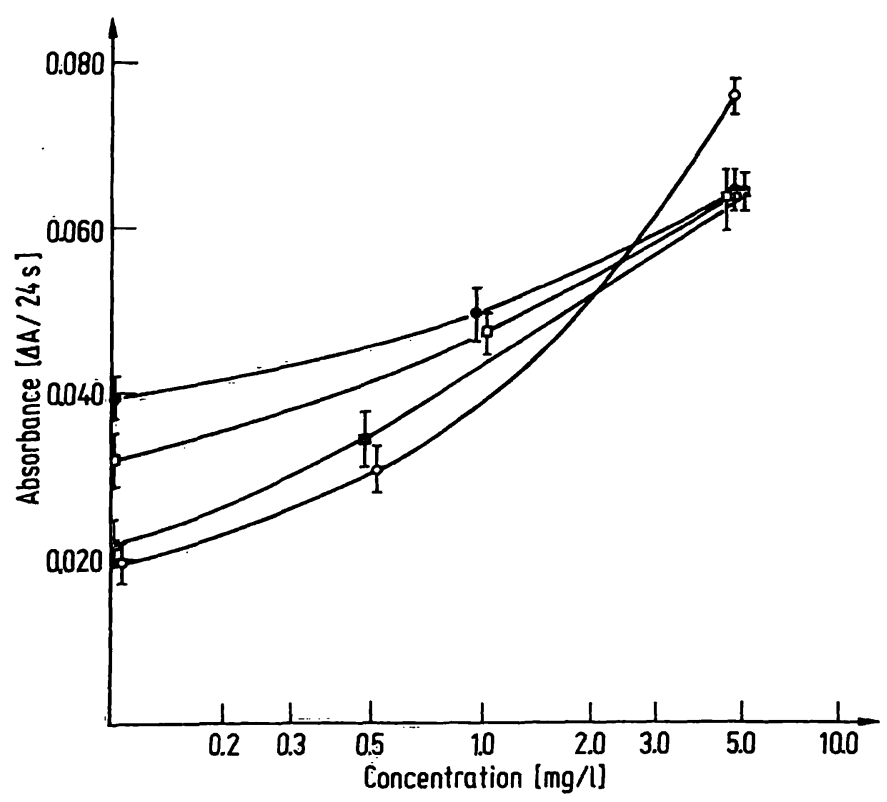

Fig. 1. Typical Emit standard curves for methadone o- 0 , morphine -a, amphetamine $\square-\square$ and secobarbital - Vertical bars represent standard deviations $(n=3)$. 
In the following the sensitivity and specificity of various Emit assays for the detection of drugs in urine and the correlation of Emit with thin layer chromatography or gas liquid chromatography are described. Results confirmed by thin layer chromatography (tab. 6) or gas liquid chromatography (tab. 7,8 ) were classified as "true", divergent values as "false" positive or negative.

\section{Barbiturates}

\section{Correlation of Emit and thin layer chromatography} with gas liquid chromatography

The results of the examination of $\mathbf{3 0 0}$ urine samples for drugs of abuse by thin layer chromatography and Emit were compared (tab. 6). About $10 \%$ of the barbiturate determinations yielded divergent results. Therefore these cases were further investigated by gas liquid chromatography. It could be demonstrated that the results of the Emit barbiturate assay correlated in

Tab. 6. Comparison of the results obtained by the Emit system and thin-layer chromatography for the detection of various drugs in urine samples from about 300 patients.

\begin{tabular}{|c|c|c|c|c|c|c|c|c|}
\hline & \multicolumn{2}{|c|}{$\begin{array}{l}\text { Emit assays } \\
\text { Barbiturate }\end{array}$} & \multicolumn{2}{|c|}{ Opiate } & \multicolumn{2}{|c|}{ Metadone } & \multicolumn{2}{|c|}{ Amphetamine } \\
\hline & $\overline{\mathrm{n}^{\mathrm{a}}}$ & $\%$ & $\mathrm{n}$ & $\%$ & $\mathrm{n}$ & $\%$ & $\mathrm{n}$ & $\%$ \\
\hline $\begin{array}{l}\text { True } \\
\text { positive }^{b}\end{array}$ & 46 & 15.3 & 8 & 2.3 & 34 & 11.5 & 2 & 0.7 \\
\hline $\begin{array}{l}\text { True } \\
\text { negative }\end{array}$ & 223 & 74.4 & 332 & 94.8 & 254 & 86.1 & 292 & 95.1 \\
\hline Total & 269 & 89.7 & 340 & 97.1 & 288 & 97.6 & 294 & 95.8 \\
\hline $\begin{array}{l}\text { False } \\
\text { positive }^{c}\end{array}$ & 10 & 3.3 & 8 & 2.3 & 6 & 2.1 & 1 & 0.3 \\
\hline $\begin{array}{l}\text { False } \\
\text { negative } c\end{array}$ & 21 & 7.0 & 2 & 0.6 & 1 & 0.3 & 12 & 3.9 \\
\hline Total & 31 & 10.3 & 10 & 2.9 & 7 & 2.4 & 13 & 4.2 \\
\hline
\end{tabular}

a $n=$ number of samples.

$b$ confirmed by thin-layer chromatography.

9 results divergent from thin-layer chromatography.

Tab. 7. Gas-liquid chromatographic confirmation of barbiturate in urine samples $(n=31)$, for which divergent results were obtained with thin-layer chromatography and the Emit system.

\begin{tabular}{|c|c|c|c|c|}
\hline & \multicolumn{2}{|c|}{$\begin{array}{l}\text { Emit barbiturate } \\
\text { assay }\end{array}$} & \multicolumn{2}{|c|}{$\begin{array}{l}\text { Thin-layer } \\
\text { chromatography }\end{array}$} \\
\hline & $\mathrm{n}^{\mathrm{a}}$ & $\%$ & $\mathrm{n}$ & $\%$ \\
\hline $\begin{array}{l}\text { True positive }{ }^{b} \\
\text { True negative } \\
\text { Total }\end{array}$ & $\begin{array}{r}5 \\
15 \\
20\end{array}$ & $\begin{array}{l}16.1 \\
48.4 \\
64.5\end{array}$ & $\begin{array}{r}8 \\
3 \\
11\end{array}$ & $\begin{array}{r}25.8 \\
.9 .7 \\
35.5\end{array}$ \\
\hline $\begin{array}{l}\text { False positive } \\
\text { False negative } \\
\text { Total }\end{array}$ & $\begin{array}{r}-- \\
3 \\
8 \\
11\end{array}$ & $\begin{array}{r}--- \\
9.7 \\
25.8 \\
35.5\end{array}$ & $\begin{array}{r}-- \\
15 \\
5 \\
20\end{array}$ & $\begin{array}{l}---- \\
48.4 \\
16.1 \\
64.5\end{array}$ \\
\hline
\end{tabular}

$\mathrm{n}=$ number of samples.

b confirmed by gas-liquid chromatography.

T) unconfirmed by gas-liquid chromatography.
Tab. 8. Comparison of the results obtained by the Emit system, thin-layer chromatography and gas-liquid chromatographie for the detection of barbiturate in urine samples from 65 patients.

\begin{tabular}{|c|c|c|c|c|}
\hline & \multicolumn{2}{|c|}{$\begin{array}{l}\text { Emit barbiturate } \\
\text { assay }\end{array}$} & \multicolumn{2}{|c|}{$\begin{array}{l}\text { Thin-layer } \\
\text { chromatography }\end{array}$} \\
\hline & $\mathrm{n}^{\mathrm{a}}$ & $\%$ & $\mathrm{n}$ & $\%$ \\
\hline $\begin{array}{l}\text { True positive }{ }^{b} \\
\text { True negative } \\
\text { Total }\end{array}$ & $\begin{array}{l}16 \\
33 \\
49\end{array}$ & $\begin{array}{l}24.6 \\
50.8 \\
75.4\end{array}$ & $\begin{array}{l}19 \\
20 \\
39\end{array}$ & $\begin{array}{l}29.2 \\
30.8 \\
60.0\end{array}$ \\
\hline $\begin{array}{l}\text { False positive } \\
\text { False negative } \\
\text { Total }\end{array}$ & $\begin{array}{r}- \\
10 \\
16\end{array}$ & $\begin{array}{r}9.2 \\
15.4 \\
24.6\end{array}$ & $\begin{array}{r}19 \\
7 \\
26\end{array}$ & $\begin{array}{l}29.2 \\
10.8 \\
40.0\end{array}$ \\
\hline
\end{tabular}

$\mathrm{n}=$ number of samples.

b confirmed by gas-liquid chromatography.

ๆ results divergent from gas-liquid chromatography.

$64.5 \%$ and those of thin layer chromatography only in $35.5 \%$ with those of gas liquid chromatography (tab. 7). A relatively high percentage of false negative results occurred with thin layer chromatography and Emit, as these methods were less sensitive than gas liquid chromatography. False positive results were observed with thin layer chromatography in $48.4 \%$ and with the Emit system in $9.7 \%$ of the determinations, indicating a rather low specificity of the thin layer chromatography.

When a larger collective of 65 patients chosen at random was tested, $75 \%$ of the results by the Emit system and $60 \%$ of those by thin layer chromatography could be confirmed by gas liquid chromatography (tab. 8). Again there were much more false positive results by thin layer chromatography than by Emit. The sensitivity of Emit however appeared to be lower than that of thin layer chromatography.

If thin layer chromatography was used in combination with Emit the percentage of false positive results could be reduced from $29 \%$ to $5 \%$ and that of false negative ones from $11 \%$ to $3 \%$. Therefore it appears to be suitable to confirm by Emit all of the positive results. Thus a considerable reduction of wrong results can be achieved very easily and only divergent results have to be analyzed by time-consuming techniques such as gas liquid chromatography. Samples negative by thin layer chromatography should be determined in addition by Emit, if barbiturate abuse is suspected, as the combination of both methods yields less false negative results.

So far urine samples from patients that suffered from barbiturate poisoning had identical results by all of the three methods mentioned above.

\section{Specificity and sensitivity}

Glutethimide was the only nonbarbiturate compound, which cross-reacted in this Emit assay. 
Tab. 9. Cross-reactivity of drugs in urine ${ }^{a}$ with the Emit amphetamine and Emit barbiturate assay.

Emit amphe tamine assay

Compound (trade name)

Amphetamine (Benzedrine)

Methamphetamine Hydrochloride (Pervitin)

Fenethylline Hydrochloride (Captagon)

Fenfluramine Hydrochloride (Ponderax)

Propylhexedrine Hydrochloride (Eventin)

Ephedrine Hydrochloride (Ephetonin)

D-Phenylethylamine

L-Phenylethylamine

Methylphenidate (Ritalin)

4-Aminophenazone

Phenylalanine

Caffeine

Strychnine Nitrate

Norfenefrine Hydrochloride (Novadral)

Oxedrine Tartrate (Sympathol)

Isoprenaline Hydrochloride (Aludrin)

Orciprenaline Sulphate (Alupent)

Bamethan Sulphate (Vasculat)

Etilefrine Hydrochloride (Effortil)

Vanilmandelic Acid
Emit barbiturate assay

Compound (trade name)

$\mathrm{mg} / \mathrm{l}$

Secobarbital (Seconal)

Pentobarbital (Neodorm)

Hexobarbital (Evipan)

Methylphenobarbital (Prominal)

Cyclopal

Vinylbarbital

Phenobarbital (Luminal)

Amobarbital (Amytal)

Cyclobarbital calcium (Phanodorm)

Amylallylbarbital calcium

Brallobarbital

Aprobarbital (Numal)

Heptabarbital (Medomin)

Butabarbital

Propallylonal

Butalbital (Sandoptal)

Crotylbarbital

Barbital (Veronal)

Allobarbital (Dial)

Thiogenal sodium

Thiopental (Trapanal)

Enibomal sodium (Eunarcon)

Glutethimide (Doriden)

Methyprylon (Noludar)

Carbromal (Adalin)

Bemegride (Eukraton)

a) drugs were added to normal human urine.

b concentrations resulting in an absorbance equivalent to $1.0 \mathrm{mg} / \mathrm{l}$ amphetamine or secobarbital.

9 no reaction up to concentrations of $500-1000 \mathrm{mg} / \mathrm{l}$

Tab. 10. Detection limits of various drugs with the Emit system and thin-layer chromatography.

\begin{tabular}{lll}
\hline Compound & $\begin{array}{l}\text { Emit } \\
\text { system }\end{array}$ & $\begin{array}{l}\text { Thin-layer } \\
\text { chromato- } \\
\text { graphy }\end{array}$ \\
\hline Methadone (mg/l) & 0.2 & 1.0 \\
Morphine (mg/l) & 0.3 & 0.6 \\
Amphetamine (mg/l) & 0.4 & 1.0 \\
Secobarbital (mg/l) & 0.5 & 1.0 \\
\hline
\end{tabular}

a) These detection limits are based on the extraction of $20 \mathrm{ml}$ urine.

Most of the barbiturates were detectable by Emit at concentrations between 1 and $10 \mathrm{mg} / 1$ (tab. 9). The detection limit of secobarbital was $0.5 \mathrm{mg} / 1$ (tab. 10). With all Emit assays tested the detection limits, however, were not used as "cut-off" values between negative and positive results. In agreement with the manu: facturer higher "cut-off" points were chosen, in order to decrease the risk of obtaining false positive results due to endogenous lysozyme (18). We have found it convenient to use the low calibrator reading $(1.0 \mathrm{mg} / 1$ of secobarbital) as cut-off with the Emit barbiturate assay.
Tab. 11. Detection of drugs in urine samples of a urine drug check kit ${ }^{\mathrm{a}}(\mathrm{n}=23)$ by thin-layer chromatography (TLC) and the Emit system. The urine samples contained various combinations of barbiturates $(1 \mathrm{mg} / \mathrm{l})$, opiates ( $1 \mathrm{mg} / \mathrm{l})$, amphetamines $(2 \mathrm{mg} / \mathrm{l})$ and other drugs.

Barbiturates $\begin{aligned} & \text { Morphine Methadone } \\ & \text { and deriva- } \\ & \text { tives }\end{aligned}$
TLC EMIT TLC EMIT TLC EMIT TLC EMIT
mines

Resulțs

\begin{tabular}{|c|c|c|c|c|c|c|c|c|}
\hline Correct $^{b}$ & 20 & 18 & 19 & 22 & 20 & 23 & 23 & 23 \\
\hline $\begin{array}{l}\text { False } \\
\text { negative }\end{array}$ & 1 & 4 & 2 & 0 & 0 & 0 & 0 & 0 \\
\hline $\begin{array}{l}\text { False } \\
\text { positive }^{d}\end{array}$ & 2 & 1 & 2 & 1 & 3 & 0 & 0 & 0 \\
\hline
\end{tabular}

a) Lederle diagnostics.

Total number of correct results for the indicated drug.

c, d) Total number of false negative and false positive results respectively.

As the sensitivity of the barbiturate determination by thin layer chromatography was about $1-5 \mathrm{mg} / \mathrm{l}$, the concentrations found in urine after a therapeutic barbiturate dose were detectable by both methods. 
The results of blind controls (tab. 11) showed a relatively high percentage of false negative results by Emit, as the concentrations of some of the barbiturates such as phenobarbital were already below the detection limit.

\section{Amphetamine}

\section{Sensitivity and Specificity}

Although the detection limit of amphetamine was lower with the Emit system than with thin layer chromatography (tab. 10), the practical level of sensitivity was about the same with both methods.

The specificity of the amphetamine assay appeared to be rather low in view of the detection of a number of interfering substances. Stimulants like methamphetamine (Benzedrin), fenethylline (Captagon), ephedrine (Ephetonin), propylhexedrine (Eventin) as well as anoretics such as fenfluramine (Ponderax) cross-reacted in this Emit assay at low concentrations (tab. 9). Methylphenidate (Ritalin) showed no cross-reaction.

In addition to amphetamine, various stimulants were detectable by thin layer chromatography. Unfortunately 4-aminophenazone, a metabolite of dimethylaminophenazone, behaved in our thin-layer chromatographic system like amphetamine (tab. 2). Therefore repeatedly positive results were obtained with urine samples from patients that had taken drugs such as Optalidon which contain dimethylaminophenazone. The presence of amphetamine could be excluded in these cases by Emit.

\section{Correlation of Emit with thin layer chromatography}

With the Emit amphetamine assay only very few false positive but a number of unconfirmed negative results were observed (tab. 6). The latter were mostly due to the interference of 4-aminophenazone with the thin-layer chromatographic amphetamine detection and therefore correctly negative. The analysis of blind control specimens yielded no false results (tab. 11).

However cross-reactions seem to occur, since, in contrast to our study, Mulé found $12.5 \%$ false positive results with this Emit assay (19).

\section{Morphine and derivatives}

\section{Sensitivity and specificity}

The Emit system was more sensitive for the detection of morphine than thin layer chromatography (tab. 10). According to the manufacturer's recommendations the "cut-off" value above which samples are classified as positive was chosen to be $0.5 \mathrm{mg} / 1$. A further advantage of the Emit system was the additional detection of morphine glucuronide (18) and the small sample size of
$50 \mu \mathrm{l}$. A comparable sensitivity was attained by thin layer chromatography, providing $20 \mathrm{ml}$ of urine were extracted. Various narcotic drugs listed in table 2 were detectable by thin layer chromatography at concentrations of $0.6-5.0 \mathrm{mg} / 1$.

The term Emit opiate assay seems to be incorrect, as this test shows sufficient sensitivity only for few opiates such as morphine, codeine and levorphanol (tab. 12). Therefore the expression "Emit morphine derivatives assay" would perhaps be more suitable.

The cross-reaction of codeine interferes with the detection of morphine abuse. Positive results are found very often with urine samples from patients taking cough drops, which contain codeine. Therefore the sole use of the Emit opiate assay is only suited for the exclusion of the opiates mentioned above.

\section{Correlation of Emit with thin layer chromatography}

Divergent results were obtained by Emit and thin layer chromatography in only in $2.9 \%$ of the determinations (tab. 6). The greater sensitivity of the immunoassay appeared to be responsable for the majority of the unconfirmed results. Similar data have been reported by Mule (19). With the analysis of blind control specimens more false results were obtained by thin layer chromatography than by Emit (tab. 11).

\section{Methadone}

\section{Sensitivity and specificity}

Methadone was detectable by Emit at lower concentrations than by thin layer chromatography (tab. 10). With the Emit system values above $0.5 \mathrm{mg} / \mathrm{l}$ were classified as positive results.

The Emit methadone assay showed no absolute specificity. Normethadone (tab. 12) and metabolites of $L=\alpha$-acetyl methadol (30) were found to cross-react in this assay.

The methadone detection by thin layer chromatography appeared to be less specific. With blind control specimens false positive results were observed by thin layer chromatogräphy but not by Emit (tab. 11).

Metabolites of methadone do not cross-react in the Emit assay $(19,30)$. One metabolite of methadone was detectable by thin layer chromatography (tab. 2). The excretion of methadone and its metabolite depends on the $\mathrm{pH}$ value of the urine: the ratio of methadone metabolite/methadone is 1.0 at a pH of 4-5 and 40 at a $\mathrm{pH}$ of $7.4=8.1$ (31). Thus the detection of the methadone metabolite in alkaline urine by thin layer chromatography may be helpful in the detection of the use of methadone. 
Tab. 12. Cross-reactivity of drugs in urine $\mathrm{a}^{\mathrm{a}}$ with the Emit methadone and opiate assay.

Emit methadone assay

Compound (trade name)

Methadone

Normethadone (Ticarda)

Promethazine hydrochloride (Atosil)

Chlorpromazine hydrochloride (Megaphen)

Morphine hydrochloride

Codeine phosphate

Pethidine hydrochloride (Dolantin)

Levallorphan tartrate (Lorfan)

Levorphanol tartrate (Dromoran)

Ketobemidone (Cliradone)

Dextromoramide (Palfium)

Dextropropoxyphene

Triflupromazine hydrochloride (Psyquil)
Emit opiate assay

$\mathrm{mg} / \mathrm{l}^{\mathrm{b}}$
0.5
4.0
130.0
150.0
190.0
$\mathrm{NR}$
$\mathrm{NR}$
$\mathrm{NR}$
$\mathrm{NR}$
$\mathrm{NR}$
$\mathrm{NR}$
$\mathrm{NR}$
$\mathrm{NR}$

Morphine
Compound (trade name)

$\mathrm{mg} / 1$

Codeine phosphate

Levorphanol tartrate (Dromoran)

Ketobemidone (Cliradon)

Pethidine hydrochloride (Dolantin)

Levallorphan tartrate (Lorfan)

Promethazine hydrochloride (Atosil)

Chlorpromazine hydrochloride (Megaphen)

Triflupro mazine hydrochloride (Psyquil)

Methadone hydrochloride ( $L$-Polamidon)

Normethadone (Ticarda)

Dextromoramide (Palfium)
0.5

0.4

2.5

50.0

70.0

100.0

260.0

310.0

NR

NR

NR

NR

a) drugs were added to normal human urine. ${ }^{\text {) }}$ concentrations resulting in an absorbance equivalent to $0.5 \mathrm{mg} / \mathrm{l}$ methadone or morphine. 9 no reaction up to concentrations of $500-1000 \mathrm{mg} / \mathrm{l}$.

\section{Correlation of Emit with thin layer chromatography}

The comparison of the results obtained by Emit and thin layer chromatography in a series of about 300 patients showed a good correlation between both methods. Only $2.4 \%$ of the results could not be confirmed by thin layer chromatography. The major reason for this discrepancy seemed to be the greater sensitivity of the Emit system. This finding is consistent with observations of Mulé (19).

\section{Comparison of costs}

The costs for reagents, pertinent supplies, standards and technician time are listed in table 13. A detailed calculation of the costs for technician time is reported by 1 . c. (32); meanwhile a presumable 36 percent increase of labor costs was considered in our calculation. If 30 samples were analyzed the price for a thin layer chromatography-screening was about $6 \mathrm{DM}$ and per Emit test $4 \mathrm{DM}$. The costs for thin layer chromatography rise considerably, if commercially available toxicological control urine is used. Single determinations are very expensive with both methods.

\section{Conclusion}

From the results of our study the following procedure for the detection of drugs is recommended (fig. 2):

At first a thin-layer chromatographic screening test is performed, which allows the detection of a large variety of drugs.

Results positive for barbiturates, opiates or amphetamines have to be confirmed by the corresponding Emit assay. If divergent results are obtained, the further investigation by a more specific method such as gas liquid chromatography is necessary. In cases of suspected abuse of barbiturates and opiates the additional performance of the corresponding Emit assays is useful, even if the thin layer chromatography screening is negative.

Further Emit assays for the determination of the metabolites of cocaine and benzodiazepine are available and may be integrated into this scheme. Frequently abused drugs such as bromoureides have to be determined by other methods.

Tab. 13. Costs of a thin-layer chromatographic screening (Drug-Skreen) and of an Emit test (Drug Abuse Urine Assay).

\begin{tabular}{|c|c|c|c|c|c|c|c|}
\hline \multirow[t]{2}{*}{ Costs } & & \multicolumn{3}{|c|}{ Thin-layer chromatography } & \multicolumn{2}{|c|}{ Emit assay } & \multirow[b]{2}{*}{$\mathrm{n}=50$} \\
\hline & & $n^{2}=1$ & $\mathrm{n}=\mathbf{3 0}$ & $n=50$ & $\mathrm{n}=1$ & $\mathrm{n}=\mathbf{3 0}$ & \\
\hline $\begin{array}{l}\text { Technician time } e^{b} \\
\text { Reagents and pertinent supplies } \\
\text { Standards }\end{array}$ & $\begin{array}{l}\mathrm{DM} \\
\mathrm{DM} \\
\overline{\mathbf{D M}}\end{array}$ & $\begin{array}{r}28.50 \\
8.76 \\
0.04 \\
(33.30)\end{array}$ & $\begin{array}{c}3.80 \\
2.59 \\
0.01 \\
(4.44)\end{array}$ & $\begin{array}{r}2.52 \\
2.54 \\
<0.01 \\
(4.00)\end{array}$ & $\begin{array}{r}9.90 \\
21.56 \\
6.00\end{array}$ & $\begin{array}{l}1.00 \\
3.09 \\
0.20\end{array}$ & $\begin{array}{l}0.81 \\
2.83 \\
0.12\end{array}$ \\
\hline Total & DM & $\begin{array}{c}37.30 \\
(70.56)\end{array}$ & $\begin{array}{c}6.40 \\
(10.83)\end{array}$ & $\begin{array}{c}5.06 \\
(9.06)\end{array}$ & 37.46 & 4.29 & 3.76 \\
\hline
\end{tabular}

9 $n=$ number of specimens per series. 9 costs per minute technician time: $0.30 \mathrm{DM} .9$ prices in parenthesis refer to the use of toxicological control urine (Lederle diagnostics). 


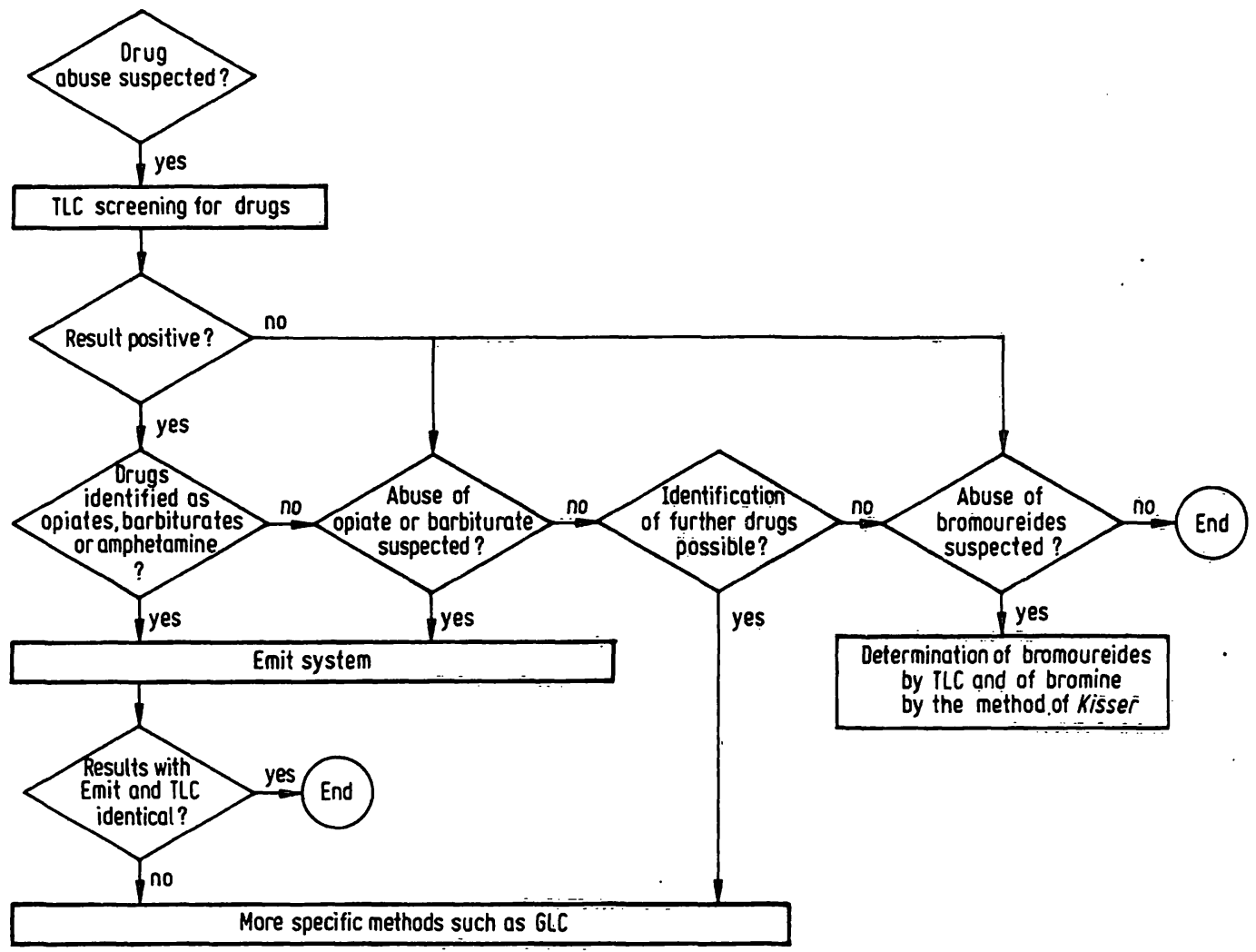

Fig. 2. Flow scheme for the detection of drugs in urine.

TLC $=$ Thin layer chromatography. GLC $=$ Gas liquid chromatography.

By the use of the procedure described above the quality of drug screening is considerably improved. The number of false positive results is reduced. In the detection of barbiturates false positive results decreased from $29 \%$ to $5 \%$. The presence of amphetamine could be excluded by Emit, when false positive results due to the interference of 4-aminophenazone occurred. Wrong results for methadone, morphine and codeine could be eliminated. Because of the greater sensitivity of Emit less false negative results were obtained in cases of suspected morphine and methadone abuse.

Furthermore time and costs are saved because the only results confirmed by gas liquid chromatography, are

\section{References}

1. Sunshine, I. (1963), Am. J. Clin. Pathol. 40, 576-582.

2. Davidow, B., Petri, N. L., Babington, B. S., Quame, M. S., Searle, B., Fostlich, M. S. \& Saritzky, J. (1966), Am, I. Clin. Pathol. 46, 58-62.

3. Davidow, B., Petri, N. L. \& Quame, B. (1968), Am. J. Clin. Pathol. 50, 714-719.

4. Dole, V. P., Kim, W. K. \& Eglitis, J. (1966), J. Am. Med. Ass. $198,115-118$.

5. Mulé, S. J. (1969), J. Chromatogr. 39, 302-311.

6. Bastos, M. L., Kananen, G. E., Young, R. M., Monteforte, J. R. \& Sunshine, J. (1970), Clin. Chem. 16, 931-940.

7. Berry, D. J. \& Grove, J. (1973), J. Chromatogr. 80, 205-219. those which are divergent by thin layer chromatography and Emit. This seems to be important, if a rapid screening of a large number of specimens is required. In this case the confirmation of every positive result by gas liquid chromatography would lead to an enormous workload and to a delay of the results.

The described screening procedure appears to be suitable for routine urine testing and toxicological emergencies such as barbiturate poisoning. In accordance with the results of Mule (19) and McIntyre (30) the Emit system can be regarded as a valuable contribution to existing screening methods for the detection of drugs of abuse.
8. Fujimoto, J. M. \& Wang, R. I. H. (197.0), Toxikol. Appl. Pharmacol. 16, 186-193.

9. Bastos, M. L., Jukovsky, D., Saffer, E., Chedekel, M. \& Mulé, S. J. (1972), J. Chromagr. 71, 549-553.

10. Hetland, L. B., Knowlton, D. A. \& Couri, D. (1972), Clin. Chim. Acta 36, 473-478.

11. Miller, W. L, Kullberg, M. P., Banning, M. G., Brown, L. D. \& Doctor, B. P. (1973), Biochem. Med. 7, 145-158.

12. Weissman, N., Lowe, M. L., Beattie, J. M. \& Demetriou, J. A. (1971), Clin. Chem. 17, 875-881.

13. Coumbis, R. J., Fulton, C. C., Calise, J. P. \& Rodriguez, C. (1971), J. Chromatogr. 54, 245-250. 
14. Adler, F. L. \& Lin., C. (1971), J. Immunol. 106, 1684 -1685 .

15. Leute, R. K., Ullman, E. F., Goldstein, A. \& Herzenberg, L. A. (1972), Nature New Biol. 236, 93-94.

16. Spector, S. \& Parker, C. W. (1970), Science 168,1347 $-1348$.

17. Rubenstein, K. E., Schneider, R. S. \& Ullman, E. F. (1972), Biochem. Biophys. Res. Commun. 47, 846-851.

18. Schneider, R. S., Lindquist, P., Wong, E. T., Rubenstein, K. E. \& Ullman, E. F. (1973), Clin. Chem. 19, 821-825.

19. Mulé, S. J., Bastos, M. L. \& Jukof sky, D. (1974), Clin. Chem. 20, 243-248.

20. Broughton, A, A. \& Ros, D. L. (1975), Clin. Chem. 21, 186-189.

21. Mulé, S. J., Whitlock, E. \& Jukofsky, D. (1975), Clin. Chem. $21,81-86$.

22. Catlin, D. H. (1973), Am. J. Pathol. 60, 719-728.

23. Gorodetzky, C. W., Angel, C. R., Beach, D. J., Catlin, D. H. \& Yek, S. Y. (1973), Clin. Pharmacol. Ther. 15, 461-472.
24. Kaiser, H. (1965), Z. Analyt. Chem. 209, 1-18.

25. Pippenger, Ch. E., Bastiani, R. J. \& Schneider, R. S. in Clinical Pharmacology of Antiepileptic Drugs (Schneider, $H$. \& Janz, D. ed.), Berlin, Springer 331-335.

26. Booker, H. E. \& Darcey, B. A. (1975), Clin. Chem. 21, 1766-1768.

27. Spiehler, U., Sun, L., Miyada, D. S., Sarandis, S. G., Walwick, E. K., Klein, M. W., Jordan, D. B. \& Jessen, B. (1976), Clin. Chem. 22, 749-753.

28. Legaz, M. \& Raisys, V. A. (1976), Clin. Biochem. 9, 35-38.

29. Oellerich, M., Külpmann, W. R., Haeckel, R. \& Heyer, R. (1977), J. Clin. Chem. Clin. Biochem. 15, 353-358.

30. McIntyre, J. A., Armandi, A. E., Risen, L. P., Ling, W. \& Haberfelde, G. C. (1975), Clin. Chem. 21, 109-112.

31. Beckett, A. H. (1969), Scientific basis of drug dependence (Steinberg, H. ed.), J\&A Churchill, Ltd., London, 129-148.

32. Haeckel, R, Höpfel, P. \& Höner, G. (1974), this j. 12, 14-22.
Dr. M. Oellerich Institut für Klinische Chemie Karl-Wiechert-Allee 9 D-3000 Hannover 61 
